\title{
Sowing uniformity of bed-type pneumatic maize planter at various seedbed preparation levels and machine travel speeds
}

\author{
Fiaz Ahmad ${ }^{1,2 \dagger}$, Muhammad Adeel ${ }^{2 \dagger}$, Baijing Qiu ${ }^{1 *}$, Jing Ma ${ }^{1}$, Muhammad Shoaib ${ }^{2}$, \\ Aamir Shakoor ${ }^{2}$, Farman Ali Chandio ${ }^{1,3}$ \\ (1. School of Agricultural Equipment Engineering, Jiangsu University, Zhenjiang 212013, Jiangsu, China; \\ 2. Department of Agricultural Engineering, Bahauddin Zakariya University, Multan 60800, Pakistan; \\ 3. Department of Farm Power and Machinery, Sindh Agriculture University, Tando Jam 70060, Pakistan)
}

\begin{abstract}
Precision planters are important machines in the regime of modern technological agriculture. Field conditions, seed metering system and machine operating parameters affect the pneumatic planter performance. The pneumatic planter was evaluated to determine the effect of three tillage levels $\left(L_{1}, L_{2}\right.$, and $\left.L_{3}\right)$ and four travel speeds $\left(S_{1}, S_{2}, S_{3}\right.$ and $\left.S_{4}\right)$. The sowing uniformity of the planter was observed with respect to the horizontal distribution of seeds within a row and described by using the precision index $\left(I_{p}\right)$, the multiple index $\left(I_{\text {mult }}\right)$, the miss-seeding index $\left(I_{\text {miss }}\right)$ and the quality of feed index $\left(I_{q f}\right)$. The results revealed that the tillage levels $(L)$ and travel speed $(S)$ had a significant effect $(p<0.05)$ on dependent variables. The maximum $I_{\text {miss }}(22.12 \%)$ was observed at $L_{1}$ and $S_{4}$ whereas the maximum $I_{\text {mult }}$ was observed at $L_{1}$ and $S_{1}$. The mean values of missing-, multi-, quality- feed and precision indices were $5.14 \%, 5.833 \%, 89.03 \%$ and $17.85 \%$ at $L_{3}$, respectively. The mean values of multi-index $17.59 \%, 14.44 \%, 12.40 \%$ and $10.18 \%$, quality feed index $74.07 \%, 75.92 \%, 75.74 \%$ and $74.07 \%$ and precision indices $21.47 \%, 23.26 \%, 25.51 \%$ and $28.53 \%$ were at $S_{1}, S_{2}, S_{3}$ and $S_{4}$, respectively. The study showed that maize could be seeding within an acceptable precise range by bed-type pneumatic planter subjected to the proper seedbed preparation level.
\end{abstract}

Keywords: sowing uniformity, pneumatic planter, tillage levels, travel speed

DOI: $10.25165 /$ j.ijabe.20211401.5054

Citation: Ahmad F, Adeel M, Qiu B J, Ma J, Shoaib M, Aamir S, et al. Sowing uniformity of bed-type pneumatic maize planter at various seedbed preparation levels and machine travel speeds. Int J Agric \& Biol Eng, 2021; 14(1): 165-171.

\section{Introduction}

Maize is one of the most significant cereal crops in the world with the highest yield. With an annual production of nearly 600 million $\mathrm{t}$ from the cultivation area of approximately 118 million $\mathrm{hm}^{2}$, maize stands at third position among the most cultivated crops in the world. Maize produced in Pakistan comes at the fourth position only after wheat, cotton, and rice with a production volume of 3.5 million $t$ grown on an area of more than a million hectares. Maize cultivation during the year 2017-2018, has been increased to an area of 1144 thousand $\mathrm{hm}^{2}$, with an increase of $0.2 \%$ from the previous year ${ }^{[1]}$.

Precision planters are machines of significant importance in the regime of modern technological agriculture, where the highest precision is required with the lowest consumption of energy labor and $\operatorname{cost}^{[2]}$. Generally, precision planter consists of both

\section{Received date: 2019-04-03 Accepted date: 2020-03-20}

Biographies: Fiaz Ahmad, Post PhD Fellow/Assistant Professor, research interest: agricultural machinery, Email: engrfiaz@yahoo.com; Muhammad Adeel, Master, research interest: testing of agriculture machinery, Email: engr.raoadeel@gmail.com; Jing Ma, PhD student, research interest: agriculture engineering, Email: ma_jiang0716@163.com; Muhammad Shoaib, Assistant Professor, research interest: soil mechanics, Email: muhammadshoaib@ bzu.edu.pk; Amir Shakoor, Assistant Professor, research interest: soil mechanics, agricultural machinery, Email: aamirskr@yahoo.com; Farman Ali Chandio, Associate Professor, research interest: agricultural machinery, Email: farman@sau.edu.pk.

$\uparrow$ These authors have equal contributions.

*Corresponding authors: Baijing Qiu, Professor, research interest: agricultural machinery. School of Agricultural Equipment Engineering, Jiangsu University, Zhenjiang 212013, China. Tel: +86-13815177791, Email: qbj@ujs.edu.cn. conventional (furrow openers, fertilizer device, press wheel, and covering device) and nonconventional components (depth control unit, power transmission system, modern seed metering mechanism). However, the actual structure and working principle of maize planters vary due to the difference in the geographical environment, climate condition, cropping system and farm-scale among different countries and areas ${ }^{[3]}$. As the main component of the precision planter, the seed metering system should have reliable performance, stable and ease to adoptable. This precision seeding system may either be mechanical or pneumatic. Seed spacing uniformity is an important indicator in evaluating seed drill performance because a uniform distribution of seeds can not only provide maximum space for each plant but also make for uniform root size, which can increase yields and reduce harvest $\operatorname{loss}^{[4,5]}$. Thus, productivity depends on the spatial distribution of plants in the crop field. Therefore, the main objective of the precision planter is to place the seed at the required seed space and depth for the highest plant population as well as yield ${ }^{[3]}$. Seeding uniformity determination is an important parameter of seed metering evaluation ${ }^{[6]}$. The distance between plants within a row is influenced by some factors, such as failure of seed to be dropped, multiple seeds dropped at the same time, failure of seeds variability to emerge, and the around the drop point ${ }^{[7]}$. The five parameters are the main index of seeding accuracy including the quality of feed index, the multiple index, the miss-seeding index, the mean spacing and the and precision index ${ }^{[8-10]}$.

Various studies were conducted to design and evaluate the performance of the pneumatic planting system ${ }^{[4-6,11-18]}$. Yang et al. ${ }^{[3]}$ reviewed the research progress and development of precision maize planters and concluded that the usage, modification and 
improvement in the pneumatic planter depended upon the geophysical and climatic crop requirements. To obtain better uniformity of seed spacing, different optimum design and simulation methods are used on seed meters to ensure their planting quality more accurate. Karayel et al. ${ }^{[8]}$ conducted to develop a mathematical model for vacuum pressure of pneumatic seed. Singh $^{[9]}$ conducted a study on design optimization and operational parameters (pressure and disc speed) of a pneumatic cotton seeder. Regression equations were developed considering the vacuum pressure and disc speed as the independent variable and uniformity indices as the dependent variable. Jia et al. ${ }^{[19]}$ conducted a study to overcome the unfavorable factors of ground wheel-driven chain transmission when a no-tillage planter was operated on straw mulching fields with a friction wheel transmission. Moreover, the driving system for seed meters is changed from ground-wheel and chain-sprocket to electrical motor to drive precision seed unit that can change the rotational speed of metering unit with respect to forward traveling thus to eliminate the effects of ground-wheel slippage on sowing quality and get more uniform seed spacing ${ }^{[16]}$. In addition, a seed delivery system that transports seeds from seed meter to seed-bed is being developed to prevent the bump and skip between seeds and seed-tube, and as a result to maintain the uniformity of seed distribution ${ }^{[2,12,20]}$. Liu et al. ${ }^{[21]}$ investigated the relationship between the working parameters (the seeding rate and the airflow rate) and the test indexes ( $\mathrm{CV}$ of evenness of feeding rate between rows and $\mathrm{CV}$ of seeding stability of total rows) of pneumatic seeding system, MATLAB software was used to simulate the regression equations. Arzu and Adnan ${ }^{[22]}$ conducted a study for optimization the performance related to sowing uniformity of a vacuum-type precision seeder by the application of surface methodology.

The planter performs four significant functions. Firstly, the planter opens the furrow where the plantation has to be done. Then the seeds are metered in a metering device. After this metering, seeds are retained in the furrow. The fourth function of the planter includes covering the seeds forming a condensed layer of soil over them. All these functions influence the efficiency of the planter in some or another way. The process of seed placement is crucial for the success of crop cultivation ${ }^{[23-25]}$. The productivity of plantations depends on the spatial distribution of crops. As tillage methodology/intensity and sowing machinery operation changed the sowing uniformity and emergence indices ${ }^{[26]}$ therefore, the present study was conducted to evaluate the performance of pneumatic bed type maize planter affected by various tillage levels/pulverizing levels and forward speed.

\section{Materials and methods}

\subsection{Study site}

A field experiment was conducted at Experimental Farm of Department of Agricultural Engineering, Bahauddin Zakariya University, Multan, Pakistan during March-April 2018. An experimental field with a size of $26.82 \mathrm{~m}$ ( $\mathrm{E}$ to $\mathrm{W}$ ) width and $57.30 \mathrm{~m}(\mathrm{~N}$ to $\mathrm{S})$ length was prepared for field test using a four-row bed type pneumatic maize planter (Agritech model, Agritech Industries, Multan, Pakistan) (Figure 1).

\subsection{Working principle of pneumatic maize planter}

The main part of the planter had perforated discs and a circular rotating suction box which created the vacuum pressure in the four rubber pipes of the $60 \mathrm{~mm}$ diameter side (Figure 2). There was a blower fan of $4500 \mathrm{r} / \mathrm{min}$ and $530 \mathrm{~mm}$ diameter width driven by the power take-off PTO shaft, the blower shaft of $35 \mathrm{~mm}$ diameter and $195 \mathrm{~mm}$ length. The four rubber pipes were attached with the seed metering device at the top which was creating suction in the seed metering device from twenty-five holes in the perforated disc plate due to suction pressure the hybrid seeds of corns were pick up and attached with wholes of perforated plate, and the plate was rotating on it specific speed $(\mathrm{m} / \mathrm{s})$. Moreover lower side of some part of seed metering device is open to the atmospheric pressure and so that the vacuum (suction pressure) is released from that seed which is passing out from that opened portion of the seed metering device and finally dropping from the seed opener on the field after the dropping of seed. The seed is covered by the soil by a bed shaper. All the above operational principle is relevant to the pneumatic process of the planter (Figure 1).

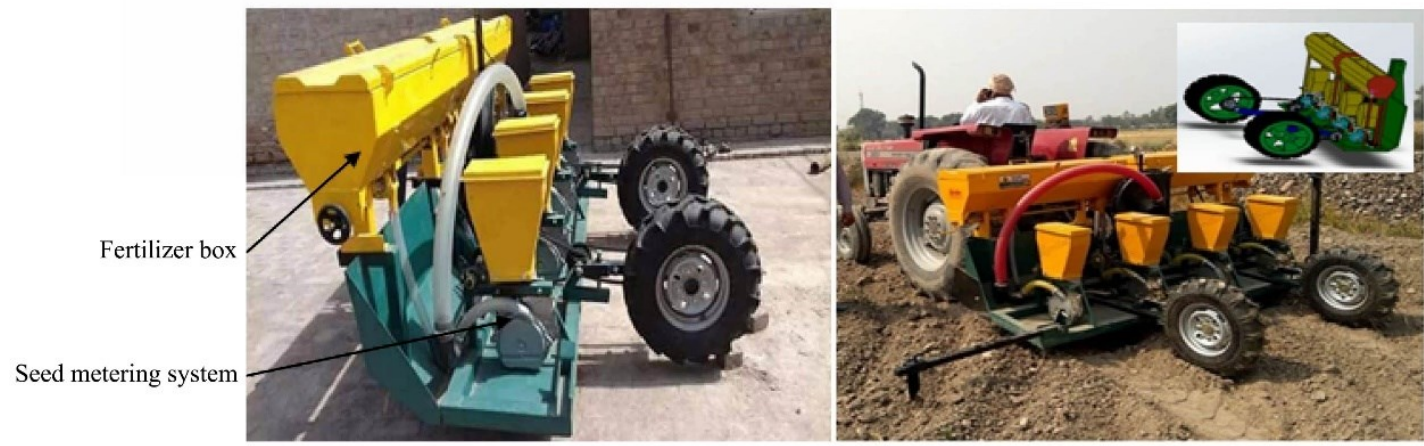

Figure 1 Pneumatic Planter (AgriTech Model)

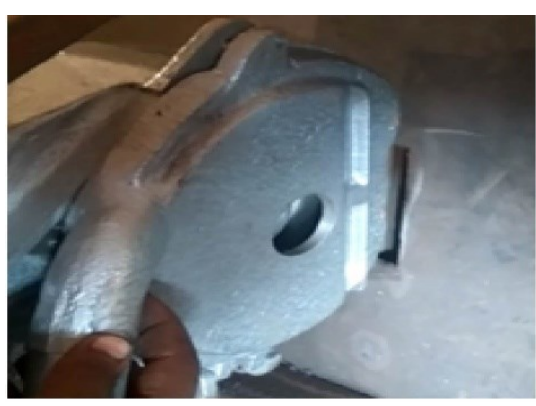

a. Pneumatic seeding unit

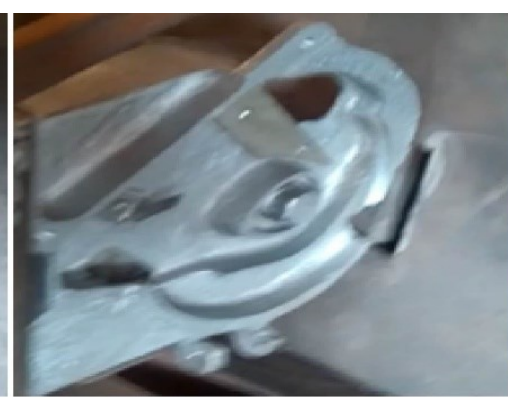

b. Inner part

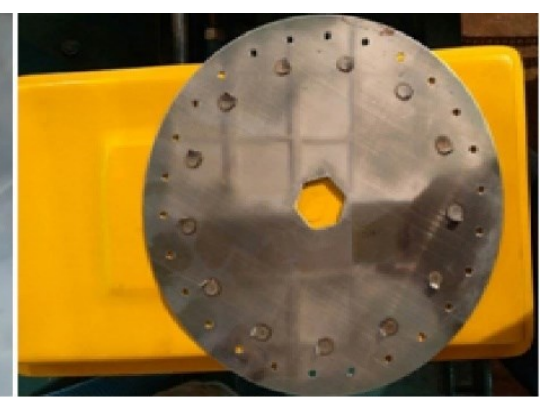

c. Rotating plate

Figure 2 Pneumatic seed metering system 
The overall working design and principle parts of the planter are discussed now. To drive the planter, greater than 50 horsepower tractors are needed. The planter had the capacity to develop four rows with the row to row spacing of $685 \mathrm{~mm}$ (adjustable). In the seed metering mechanism, the pneumatic type plates were used. The drive mechanism of the planter was through the ground wheel which had the chain sprocket linkage with the seed metering device. A bed shaper plate with the size of $2760 \mathrm{~mm} \times 65 \mathrm{~mm} \times 6 \mathrm{~mm}$ was made of mild steel. The seed hopper above the seed metering device continuously drops the seed in the seed metering device.

The fertilizer tank was also mounted in the planter on top which is wide enough for the whole width of the planter. The strong vacuum fan helps each seeding unit to suck and pick up each hybrid seed and place it on the required spacing of plant to plant, and line to line, to attain the maximum required plant population (usually 30000 to 35000 ) for maximum yield and place a fertilizer band 2 " to $2.5^{\prime \prime}$ below the seed and form required sized furrows for best water management.

There was no crop residue and rocks present in the soil. However, there were hard clay clods in the soil. In Table 2, the bulk density and moisture content (MC) before sowing is shown in the upper $45 \mathrm{~mm}$ of the soil. These parameters were measured to this depth of $45 \mathrm{~mm}$ with the help of a $50 \mathrm{~mm}$ diameter cylinder having a length of $150 \mathrm{~mm}$. Samples of the soil from the cylinder were distracted by using a plunger. Maize seed (Ravi RS-7677) was used for the field experiment in all treatments.

\section{Table 1 Four row bed type pneumatic maize planter specifications}

\begin{tabular}{|c|c|}
\hline Item & Values and description \\
\hline Type & Pneumatic, bed shaper cum planter cotton, may maze, sunflower, soybeans, etc. \\
\hline Linkage category & I \& II \\
\hline Tractor power & $50+\mathrm{hp}$ \\
\hline Nos. of rows & 4 \\
\hline Row spacing & $685 \mathrm{~mm}$ (adjustable) \\
\hline Seed metering & Plate type (pneumatic) \\
\hline Drive mechanism & Through ground wheel \\
\hline Overall dimensions & $1910 \mathrm{~mm}$ (Length) $\times 1600 \mathrm{~mm}($ Height $) \times 2760 \mathrm{~mm}($ Width $)$ \\
\hline Approx. weight & $450 \mathrm{~kg}$ \\
\hline Frame & 2 Nos. $75 \mathrm{~mm} \times 75 \mathrm{~mm} \times 6 \mathrm{~mm}$ M.S box, widthwise and on sides \\
\hline Mast (A-frame) & $60 \mathrm{~mm} \times 12 \mathrm{~mm}$ M.S. flat \& $50 \mathrm{~mm} \times 12 \mathrm{~mm}$ M.S. flat \\
\hline Hitch & $65 \mathrm{~mm} \times 65 \mathrm{~mm} \times 6 \mathrm{~mm}$ M.S. box \\
\hline Bed shaper plate & $2760 \times \mathrm{mm} 860 \mathrm{~mm} \times 4 \mathrm{~mm}$ M.S. formed sheet \\
\hline Furrow opener with wings & $\begin{array}{l}\text { M.S. plate } 12.5 \mathrm{~mm} \text { of the tip and M.S. plate } 10 \mathrm{~mm} \text { for furrow with support, } 30 \mathrm{~mm} \times 30 \mathrm{~mm} \times 4 \mathrm{~mm} \text { M.S. angle and } 4 \mathrm{~mm} \mathrm{M.S,} \\
\text { sheet for wings with support of M.S. angle } 30 \mathrm{~mm} \times 30 \mathrm{~mm} \times 4 \mathrm{~mm}\end{array}$ \\
\hline Seedbox metering frame & 04 Nos. $37 \mathrm{~mm} \times 37 \mathrm{~mm} \times 4 \mathrm{~mm}$ M.S. box \\
\hline Seed drive shaft supports & 02 Nos. M.S. channel $65 \mathrm{~mm} \times 30 \mathrm{~mm} \times 5 \mathrm{~mm}$ on the inner side and 02 Nos. M.S. box $75 \mathrm{~mm} \times 75 \mathrm{~mm} \times 5 \mathrm{~mm}$ on outside \\
\hline Browler frame & 02 Nos. M.S. angle $45 \mathrm{~mm} \times 45 \mathrm{~mm} \times 4 \mathrm{~mm}$ with supports of M.S. sheet $3 \mathrm{~mm}$ \\
\hline Blower & $\begin{array}{l}01 \text { No. (blower speed } 4500 \mathrm{r} / \mathrm{min}, 530 \mathrm{~mm} \text { dia, width } 20 \mathrm{~mm} \text { driven from PTO through flat belt, blower shaft } 35 \mathrm{~mm} \text { dia and } 195 \mathrm{~mm} \\
\text { length) with distributor and } 04 \text { Nos. rubber pipes } 36 \mathrm{~mm} \text { dia inner side }\end{array}$ \\
\hline Seedbox & 04 M.S. sheet $1.5 \mathrm{~mm}$ of $10 \mathrm{~kg}$ \\
\hline Seed plate & 04 sets for each crop \\
\hline Seed driveshaft & $22 \mathrm{~mm}$ M.S. round \\
\hline Drive mechanism & 01 No. $520 \mathrm{~mm}$ dia and $606 \mathrm{~mm}$ M.S. flat on the round plate with 50 \# chain and 11 sprockets of different size \\
\hline Row Maker & 02 hoe type $35356 \mathrm{~mm}$ M.S. box \\
\hline
\end{tabular}

Table 2 Parameters and the values measured

\begin{tabular}{lc}
\multicolumn{1}{c}{ Parameters } & Values \\
\hline Size of the field $(\mathrm{plot}) / \mathrm{m}^{2}$ & 1354.52 \\
Soil Type & Clay \\
Moisture content $/ \%$ & 3.209 \\
Bulk density $/ \mathrm{g} \cdot \mathrm{cm}^{-3}$ & 1.4 \\
Forward speed $/ \mathrm{km} \cdot \mathrm{h}^{-1}$ & $2.04,4.10,5.90,8.80$ \\
Spacing within $\mathrm{rows} / \mathrm{cm}$ & 68.6 \\
Spacing within seeds $/ \mathrm{cm}$ & $10.1,17.8,22.86$ \\
Depth of placement of seed $/ \mathrm{cm}$ & 17.78 \\
\hline
\end{tabular}

\subsection{Tillage and land preparation}

The experimental field $\left(1354.5 \mathrm{~m}^{2}\right)$ was equally divided into three main plots. Each plot had a width of $9.14 \mathrm{~m}$ and a length of $49.378 \mathrm{~m}$ with an area of $451.5 \mathrm{~m}^{2}$. The split-plot experiment was conducted with three tillage levels $\left(L_{1}, L_{2}\right.$, and $\left.L_{3}\right)$ in the main plots and the four forward speeds $\left(S_{1}, S_{2} S_{3}\right.$, and $\left.S_{4}\right)$ of the pneumatic planter in the subplot (Figure 3).

Table 3 Experimental factors, levels and level details

\begin{tabular}{|c|c|c|c|}
\hline Factors & Levels & Factor description & Plot description \\
\hline \multirow{3}{*}{ Tillage level } & $L_{1}$ & $\begin{array}{l}\text { Two passes of the cultivator, } \\
\text { one pass of disc plow and } \\
\text { one pass of rotary tiller }\end{array}$ & Main Plot \\
\hline & $L_{2}$ & $\begin{array}{l}\text { One round of chisel w plow, } \\
\text { one of disc harrow and one } \\
\text { rotary tiller }\end{array}$ & Main Plot \\
\hline & $L_{3}$ & $\begin{array}{l}\text { One round of chisel w plow, } \\
\text { one of disc harrow and two } \\
\text { passes of rotary till }\end{array}$ & Main Plot \\
\hline \multirow{4}{*}{$\begin{array}{l}\text { Forward speed } \\
\qquad / \mathrm{km} \cdot \mathrm{h}^{-1}\end{array}$} & $S_{1}$ & 2.04 & Subplot \\
\hline & $S_{2}$ & 4.04 & Subplot \\
\hline & $S_{3}$ & 5.50 & Subplot \\
\hline & $S_{4}$ & 8.80 & Subplot \\
\hline
\end{tabular}




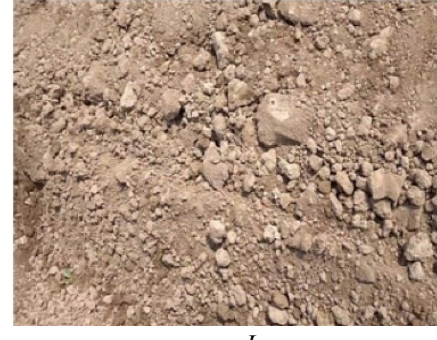

a. $L_{1}$

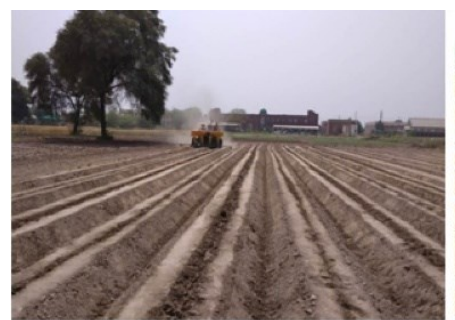

c. $L_{3}$

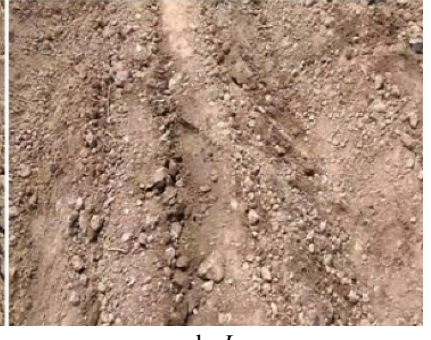

b. $L_{2}$

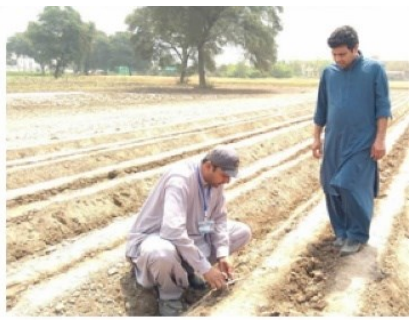

d. Filed measurement
Figure 3 Field conditions with three tillage levels

\subsection{Calibration of pneumatic planter}

Before the experimental test, the calibration test of the pneumatic planter was performed. For calibration of specific vacuum pressure, the hand liver of the tractor was lifted until that pressure was needed to be maintained. A pressure gauge reading was also recorded. The bar pressure was attained to maintain the fan speed of $4500 \mathrm{r} / \mathrm{min}$ which was a condition to stabilize the seed suction and metering mechanism. After maintaining this vacuum pressure, seed attachment to the pneumatic perforated plate was observed by opening the window of the seed metering device. The plate had all single seeds attached to its 25 holes. Pneumatic planter prepares two beds for sowing and has rows for dropping seeds in the soil.

2.5 Parameters for measuring performance during the evaluation of field

\subsubsection{Operational speed}

A stopwatch was used to calculate the time taken for traveling distance in the course of field operation. Equation (1) was used to determine the forward speed of the tractor in $\mathrm{km} / \mathrm{h}$.

$$
\text { Forward speed of tractor }=\frac{\text { Distance }}{\text { Time }} \times 3.6
$$

\subsubsection{Field capacity and field efficiency}

The actual field capacity, theoretical field capacity and field efficiency were calculated as follows:

$$
\begin{gathered}
A F C=\frac{A c}{T t} \\
T F C=\frac{W \times S}{10} \\
F C=\frac{A F C}{T F C} \times 100 \%
\end{gathered}
$$

where, $A F C$ is actual field capacity, $\mathrm{hm}^{2} / \mathrm{h} ; T F C$ is theoretical field capacity, $\mathrm{hm}^{2} / \mathrm{h} ; A c$ is the actual area covered, $\mathrm{hm}^{2} ; T t$ is the time taken, h; $F C$ is the field efficiency, $\%$; $W$ is the width of the machine, $\mathrm{m} ; S$ is the forward speed, $\mathrm{km} / \mathrm{h}$.

Kachman and Smith ${ }^{[7]}$ methods were used for analyzing the sowing uniformity of the horizontal distribution pattern.

2.5.3 Miss index

The ratio of the number of spacing $\left(N_{m s}\right)$ greater than 1.5 times of set spacing and the total number of measured spacing $(N)$ is defined as Miss Index:

$$
I_{m s}=\frac{N_{m s}}{N} \times 100 \%
$$

\subsubsection{Multiple index}

The ratio of the number of spacing $\left(N_{m t}\right) \leq 0.5$ times of set spacing and the total number of measured spacings $(N)$ is defined as Multiple Index:

$$
I_{m t}=\frac{N_{m t}}{N} \times 100 \%
$$

\subsubsection{Quality-of-feed index}

The percentage of plant spacings that were more than half but no more than 1.5 times the nominal spacing is defined as the Quality-feed index (QFI). QFI is $100 \%$ minus miss and multiple indexes and is a measure of the percentages of single seed drops.

$$
I_{q f}=100 \%-\left(I_{\text {miss }}-I_{\text {mult }}\right)
$$

\subsubsection{Precision}

The coefficient of variation of the spacings (length) between the nearest plants in a row that are classified as singles after omitting the outliers consisting of misses and multiples can be defined as preciseness. Seedling counts were made every day during the emergence period.

Precision in spacing $\left(I_{p}\right)$ is a measure of the variability (coefficient of variation) in spacing $(S)$ between seeds or plants after accounting for variability due to both multiples and misses.

$$
I_{p}=\frac{S_{d}}{S}
$$

where, $S_{d}$ is the standard deviation of the spacing more than half but not more than 1.5 times the set spacing $S$ in $\mathrm{mm}$.

\subsection{Data analysis}

A statistical software package, Statistix (version 8.1, Analytical Software, Tallahassee, FL, USA) was applied for the analysis of variance (ANOVA) and pairwise comparison. When the $F$-test pointed out statistical significance at the $p<0.05$ probability level, treatment means were separated by the least significant difference (LSD 0.05) test.

\section{Results and discussion}

\subsection{Sowing parameters affected by tillage level and travel speed}

The mean values of sowing uniformity indices presented in pneumatic bed type maize planter are presented in Table 4 . The sowing uniformity of the pneumatic bed type maize planter seeder was evaluated with respect to the multiple index, miss index, quality of feed index, and preciseness index. The effect of tillage level and forward speed of pneumatic planter on miss index $\left(I_{\text {miss }}\right)$, multiple index $\left(I_{\text {mult }}\right)$, quality of feed index $\left(I_{q f}\right)$ and precision index $\left(I_{p}\right)$ was significant $(p<0.05)$.

Table 4 Mean effect of tillage levels and forward speed on sowing uniformity indices

\begin{tabular}{cccccc}
\hline Factors & Levels & $\begin{array}{c}\text { Means of } \\
\text { missing } \\
\text { index } \\
\left(I_{\text {miss }}\right) / \%\end{array}$ & $\begin{array}{c}\text { Means of } \\
\text { multiple } \\
\text { index } \\
\left(I_{\text {mult }}\right) / \%\end{array}$ & $\begin{array}{c}\text { Means of } \\
\text { quality feed } \\
\text { index } \\
\left(I_{q f}\right) / \%\end{array}$ & $\begin{array}{c}\text { Means of } \\
\text { precision } \\
\text { index } \\
\left(I_{p}\right) / \%\end{array}$ \\
\hline \multirow{2}{*}{ Tillage } & $L_{1}$ & $17.501^{\mathrm{a}}$ & $21.944^{\mathrm{a}}$ & $60.558^{\mathrm{c}}$ & $31.075^{\mathrm{a}}$ \\
treatment & $L_{2}$ & $9.861^{\mathrm{b}}$ & $13.194^{\mathrm{b}}$ & $76.943^{\mathrm{b}}$ & $25.150^{\mathrm{b}}$ \\
& $L_{3}$ & $5.139^{\mathrm{c}}$ & $5.833^{\mathrm{c}}$ & $89.027^{\mathrm{a}}$ & $17.850^{\mathrm{c}}$ \\
\hline \multirow{2}{*}{ Forward } & $S_{1}$ & $8.331^{\mathrm{d}}$ & $17.592^{\mathrm{d}}$ & $74.074^{\mathrm{a}}$ & $21.467^{\mathrm{d}}$ \\
speed & $S_{2}$ & $9.816^{\mathrm{c}}$ & $14.444^{\mathrm{d}}$ & $75.927^{\mathrm{b}}$ & $23.261^{\mathrm{c}}$ \\
& $S_{3}$ & $11.668^{\mathrm{b}}$ & $12.407^{\mathrm{b}}$ & $75.741^{\mathrm{ab}}$ & $25.511^{\mathrm{b}}$ \\
& $S_{4}$ & $13.520^{\mathrm{a}}$ & $10.184^{\mathrm{a}}$ & $74.074^{\mathrm{a}}$ & $28.528^{\mathrm{a}}$ \\
\hline
\end{tabular}

Note: Mean values sharing the same superscript letter, for a factor, in a column do not differ significantly at $p=0.05$.

The mean values of the missing index were $17.50 \%, 9.86 \%$ and $5.14 \%$ for tillage treatment levels $L_{1}, L_{2}$ and $L_{3}$, respectively, 
indicating that missing index decreased with the increase of tillage level. As the previous crop residues and soil clods blocked the furrow opener and the seed movement in the metering system was under the effect of pneumatic pressure, thus could not place its required position ${ }^{[3]}$. The reduction in sowing uniformity of the pneumatic planter is probably a combination of several factors including negative pressure, metering system, delivery system, feel plate speed, tillage methods and forward speed ${ }^{[3,10,12,16,19,26]}$. The missing index increased with the increase of the forward speed. The highest mean missing index at forwarding speed $S_{4}(8.8 \mathrm{~km} / \mathrm{h})$ was $13.52 \%$ and the lowest at forwarding speed $S_{1}(2.04 \mathrm{~km} / \mathrm{h})$ was $8.33 \%$. Figure 4 shows the significance $(p<0.05)$ of the interactional effect of the tillage treatment level and the tractor forward speed on the missing index. The missing index decreased from $13.25 \%$ to $3.16 \%, 15.25 \%$ to $4.01 \%, 18.25 \%$ to $5.00 \%$ and $22.12 \%$ to $6.15 \%$, respectively, for forwarding speed $S_{1}, S_{2}, S_{3}$ and $S_{4}$ as the tillage level increased from $L_{1}$ to $L_{3}$. Miss index values reduced as the pressure increased but increased ${ }^{[9,11,14]}$ with the increased speed ${ }^{[6,8,10,12,14]}$. With lower vacuum pressure and at higher speeds, the metering disc does not get enough time to pick up seeds, resulting in higher miss indices ${ }^{[9,14]}$. The increase in missing index with the increase of forwarding speed might be due to the decrease in an exposure time of cell to seed in the hopper and also the higher centrifugal force at higher speeds may be the reason which throws the seed out of cell prematurely ${ }^{[6]}$.

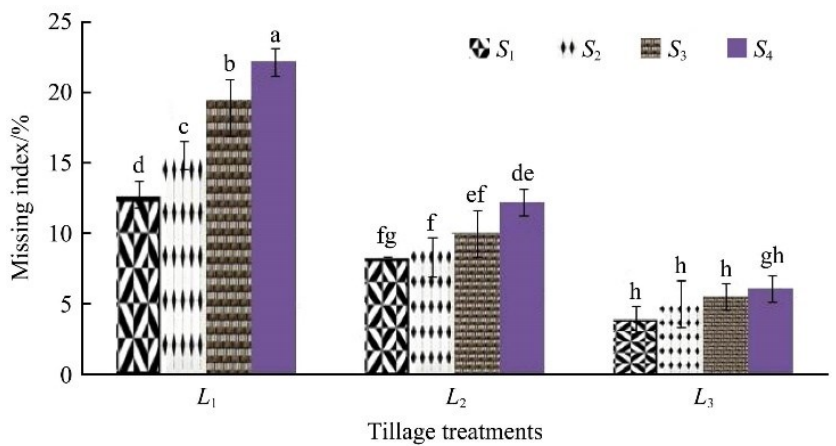

Figure 4 Interactional effects of tillage level and forward speed on missing index

The multiple indices, on the other hand, are low at higher speed but increase as the pressure increased. However, it was observed from the result that the variation in missing index with respect to change in speed was lowest at the highest tillage level $L_{3}$.

The mean values of multiple index were $21.94 \%, 13.14 \%$ and $5.83 \%$ for tillage treatment levels $L_{1}, L_{2}$ and $L_{3}$, respectively, indicating that multiple index decreased with an increase of tillage level. It might be due to the blockage of the furrow openers at the low level of tillage. With the increase in the pulverization of the seedbed, the placement of the seed increased because of the smooth running of the driving wheel of the feeding disc. The multiple index decreased with the increase of the forward speed. The highest mean multiple index at forwarding speed $S_{1}(2.04 \mathrm{~km} / \mathrm{h})$ was $17.59 \%$ and the lowest at forwarding speed $S_{4}(8.8 \mathrm{~km} / \mathrm{h})$ was $10.18 \%$. Figure 5 shows the interactional effect of the tillage treatment level and the tractor forward speed on multiple index. The multiple index increased from $4.44 \%$ to $7.78 \%, 9.45 \%$ to $16.68 \%$ and $16.67 \%$ to $28.33 \%$ for tillage level $L_{3}, L_{2}$ and $L_{1}$ as the speed decreased from $S_{4}$ to $S_{1}$ (Figure 5).

The mean values of quality feed index were $60.56 \%, 76.15 \%$ and $89.12 \%$ for tillage treatment levels $L_{1}, L_{2}$ and $L_{3}$, respectively, indicating that the quality feed index increased with the increase of tillage level. The quality feed Index was not significantly $(p>0.05)$ affected by a change in forwarding speed. Mean values of quality feed index were $74.07 \%, 75.92 \%, 75.74 \%, 74.07 \%$ at forwarding speed $S_{1}, S_{2}, S_{3}$, and $S_{4}$. Figure 6 shows the interactional effect of the tillage treatment level and the forward speed on quality feed index $\left(I_{\mathrm{qf}}\right)$. The $I_{\mathrm{qf}}$ increased from $58.58 \%$ at tillage level $L_{1}$ and speed $S_{1}$ to $89.44 \%$ at tillage level $L_{3}$ and speed $S_{4}$.

The mean values of the precision index were $31.07 \%, 25.15 \%$ and $17.85 \%$ for tillage treatment levels $L_{1}, L_{2}$ and $L_{3}$, respectively, indicating that the precision index decreases with an increase of tillage level. The precision index increased with the increase of the forward speed. The highest mean precision index at forwarding speed $S_{4}(8.8 \mathrm{~km} / \mathrm{h})$ was $28.52 \%$ and that was lowest at forwarding speed $S_{1}(2.04 \mathrm{~km} / \mathrm{h})$ was $21.47 \%$. Figure 7 shows the interactional effect of the tillage treatment level and the tractor forward speed on the precision index. The precision index decreased from $28.07 \%$ to $13.53 \%, 29.17 \%$ to $16.3 \%, 31.53 \%$ to $19.3 \%$ and $35.53 \%$ to $22.27 \%$ for forwarding speed $S_{1}, S_{2}, S_{3}$ and $S_{4}$ as the tillage level increased from $L_{1}$ to $L_{3}$. However, it was observed from the result that the variation in precision index with respect to change in speed was lowest as the highest tillage level $L_{3}$. Figure 8 shows the maize plants' emergence and spacing variation between plants sown by the pneumatic planter.

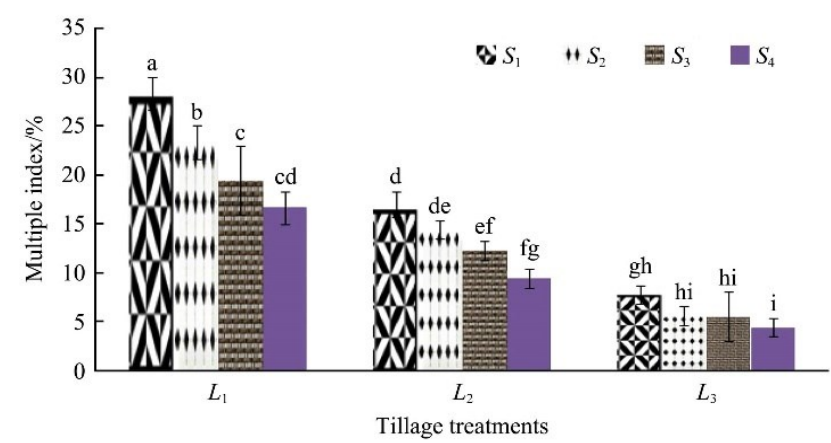

Figure 5 Interactional effect of tillage level and forward speed on multiple index

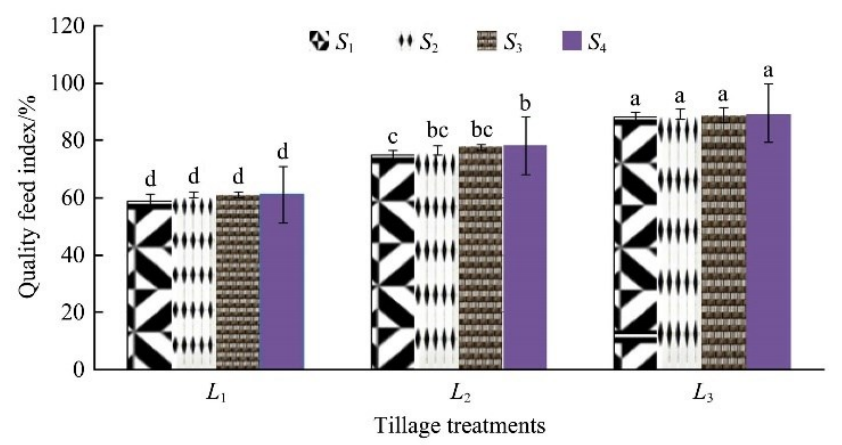

Figure 6 Interactional effect of tillage level and forward speed on quality feed index

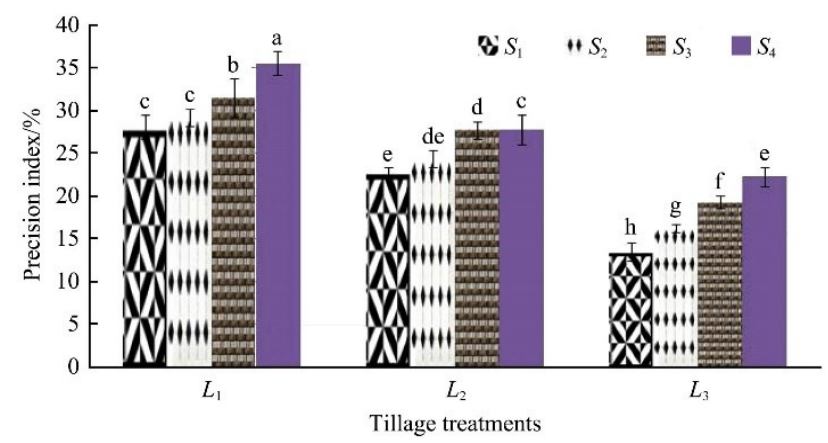

Figure 7 Interactional effect of tillage level and forward speed on precision index 

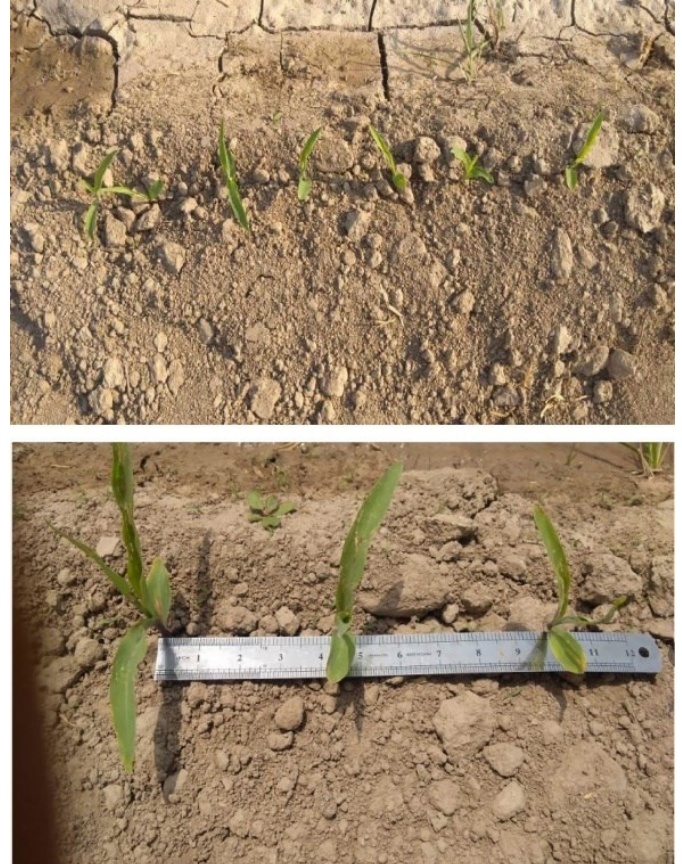

Figure 8 Maize plants emergence and spacing variation between plants sown by pneumatic planter

Seed spacing uniformity in the field is mainly influenced by the precision seed-metering system, which is the core part of a precision planter. Liu et al. ${ }^{[12]}$ conducted a study to develop the design of a precision seed delivery mechanism at high speed for maize planters. Yasir et al. ${ }^{[11]}$ found that the multiple index was higher at the lower speed of the rotating disc and declined at a higher rotating speed of the disc. Liao et al. ${ }^{[14]}$ found that the rotating speed of the feeding disc had a significant effect on uniformity indices. However, uniformity in the rotational speed of the feeding disc is a big issue under field conditions due to slippage and friction of the driving wheel. The quality feed index is highest at a negative pressure of $1600 \mathrm{~Pa}$ reported by other researchers ${ }^{[14,26]}$. Karayel and Özmerzi ${ }^{[26]}$ concluded similar findings that tillage level had a significant effect on sowing uniformity and concluded that seedbed preparation with a combination of the moldboard plow, Chisel plow and rotary tiller produced the highest uniform sowing depth.

Liu et al. ${ }^{[10]}$ reported the effect of speed on the quality feeding index. The compression of the various metering systems showed that the air pressure system had the best performance. Significant effect of tractor forward speed on the sowing uniformity indices was also reported in previous studies ${ }^{[9,27]}$ and concluded that missing index increased with the increase of the speed of feeding disc whereas the multiple index decreased with the increase of speed of feeding disc for maize seed and cotton seed. However, it was also observed that the field evaluation results significantly varied from the laboratory evaluation results of the pneumatic planter. The large differences observed in the performance indices of the laboratory and field tests are attributed to a higher miss index and multiple index. The findings of the previous studies Singh et al. ${ }^{[9]}$ show that the field evaluation is more realistic as compared to the controlled laboratory condition because in laboratory conditions the soil tool interaction is missed. Therefore, field evaluation presents a clearer picture of the pneumatic planter as compared to the laboratory evaluation and as a result, researchers can be able to modify the planter.

However, the diameter of the seed and negative pressure also influences the sowing indices (missing and multiple indices) ${ }^{[11]}$.
Therefore, in future research, a comprehensive field study is required considering negative pressure, seed dimensions, tillage level, seed delivery mechanism, number of grooves on feed plate, a rotational speed of feeding plate, forward speed and rotational speed as independent variables.

A pneumatic maize precision seed meter with combined seed holes developed by Shi et al. ${ }^{[28]}$ reached the quality of feed index up to $98.60 \%$ at the speed of $12 \mathrm{~km} / \mathrm{h}$ in speed meter testing.

\subsection{Field Capacities and field efficiency of pneumatic bed type maize planter}

When a machine achieves the actual output, it is called the effective field capacity (EFC). EFC is the utilized function proportion to the machine's width, traveling pace and the time amount delivered during the operation in the field. Figure 9 shows the comparisons of actual, theoretical field capacities and field efficiencies at four different operating forward speeds of the pneumatic planter. An increasing trend was observed in field efficiency with respect to the forward speed.

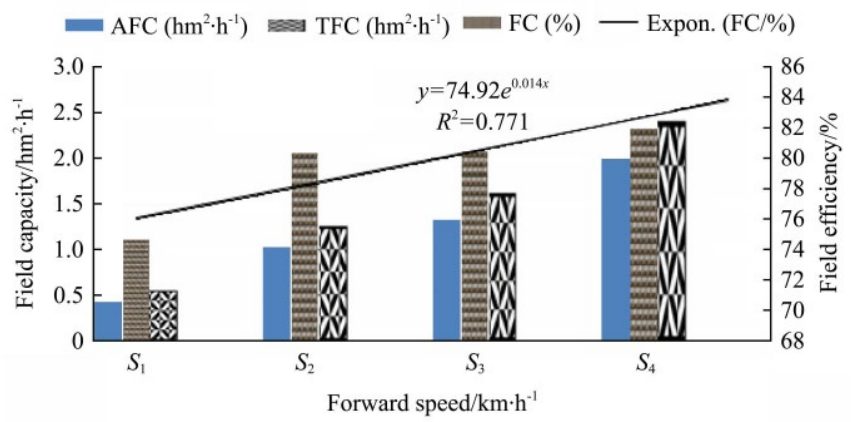

Figure 9 Relation of field capacities and field efficiency of pneumatic bed type maize planter

\section{Conclusions}

The bed type maize pneumatic plant was applied successfully for precision sowing of maize seed at different levels of seedbed preparation and machine travel speed. It was statistically proved that the uniformity indices (missing, multiple, quality feed and precision index) were significantly affected by tillage levels and travel speed. It was concluded that the pneumatic planter showed the lowest missing index and multiple index at tillage level $L_{3}$, which ultimately led to the highest quality feed index and lowest precision index. The finding of the study will be useful for the best utilization of the planter in various tillage conditions as well as provide the information for the further modification of the planter design. Further study is recommended by considering the combination of other factors such as vacuum pressure, tillage level, disc speed and machine travel speed. Discrete element simulation should also be considered to determine the sowing uniformity under dynamic conditions.

\section{Acknowledgements}

The authors acknowledge that this work was supported by the Key Research and Development Project (Grant No. 2016YFD0200708), Key Research and Development Project (Modern Agriculture) of Jiangsu Province (Grant No. BE2020328; BE2017354) and the Funded Project by Bahauddin Zakariya University, Multan (DR \& EL/D-740 dated 11-10-2017), Pakistan.

\section{[References]}

[1] Pakistan Govt. Economic Survey of Pakistan. 2018. Available: http://www.finance.gov.pk/survey_1718.html. Accessed on [2019-01-21]. 
[2] Xing H, Wang Z M, Luo X W, Cao X M, Liu C B, Zang Y. General structure design and field experiment of pneumatic rice direct seeder. Int J Agric \& Biol Eng, 2017; 10(6): 31-42.

[3] Yang L, Yan B X, Yu Y M, He X T, Liu Q W, Liang Z J, et al. Global overview of research progress and development of precision maize planters. Int J Agric \& Biol Eng, 2016; 9(1): 9-26.

[4] Zhao Z, Li Y, Chen J, Xu L Z. Numerical analysis and laboratory testing of seed spacing uniformity performance for vacuum-cylinder precision seeder. Biosystems Engineering, 2010; 106(4): 344-351.

[5] Zhang M H, Wang Z M, Luo X W, Zang Y, Yang W W, Xing H, et al. Review of precision rice hill-drop drilling technology and machine for paddy. Int J Agric \& Biol Eng, 2018; 11(3): 1-11.

[6] Grewal R S, Khurana R, Manes G S, Dixit A, Verma A. Development and evaluation of tractor operated inclined plate metering device for onion seed planting. Agric Eng Int: CIGR Journal, 2015; 17: 31-35.

[7] Kachman S D, Smith J A. Alternative measures of accuracy in plant spacing for planters using single seed metering. Transactions of the ASAE, 1995; 38: 379-387.

[8] Karayel D, Barut Z B, Ozmerzi A. Mathematical modelling of vacuum pressure on a precision seeder. Biosystems Engineering, 2004; 87(4): 437-444.

[9] Singh R C, Singh G, Saraswat D C. Optimisation of design and operational parameters of a pneumatic seed metering device for planting cottonseeds. Biosystems Engineering, 2005; 92: 429-438.

[10] Liu Q W, He X T, Yang L, Zhang D X, Cui T, Qu Z, et al. Effect of travel speed on seed spacing uniformity of corn seed meter. Int J Agric \& Biol Eng, 2017; 10(4): 98-106.

[11] Yasir S H, Liao Q X, Yu J J, He D L. Design and test of a pneumatic precision metering device for wheat. Agric Eng Int: CIGR Journal, 2012; 14: $16-25$.

[12] Liu Q W, Cui T, Zhang D X, Yang L, Wang Y X, He X T, et al. Design and experimental study of seed precise delivery mechanism for high-speed maize planter. Int J Agric \& Biol Eng, 2018; 11(4): 81-87.

[13] Zhang G Z, Zang Y, Luo X W, Wang Z M, Zhang Q, Zhang S S. Design and indoor simulated experiment of pneumatic rice seed drilling metering device. Int J Agric \& Biol Eng, 2015; 8(4): 10-18.

[14] Liao Y T, Wang L, Liao Q X. Design and test of an inside-filling pneumatic precision centralized seed-metering device for rapeseed. Int $\mathrm{J}$ Agric \& Biol Eng, 2017; 10(2): 56-62.

[15] Zhang R, Cui T, Yin X W, Zhang D X, Li K H, Han D D, et al. Design of depth-control planting unit with single side gauge wheel for no till maize precision planter. Int J Agric \& Biol Eng, 2016; 9(6): 56-64.

[16] Yin X, Noguchi N, Yang T X, Jin C Q. Development and evaluation of a low-cost precision seeding control system for a corn drill. Int J Agric \& Biol Eng, 2018; 11(5): 95-99.

[17] Bozdogan A M. Seeding uniformity for vacuum precision seeder. Sci Agric(Piracicaba, Braz), 2008; 65: 318-322.

[18] Mursec B, Vindis P, Janzekovic M, Brus C F. Testing of quality of sowing by pneumatic sowing machines. Journal of Achievements in Materials Engineering, 2008; 26: 81-88.

[19] Jia H L, Zhang Z, Chen Z, Zheng T Z, Zhao J L, Guo M Z. Friction wheel transmission of no-tillage corn planters. Int J Agric \& Biol Eng, 2017; 10(4): 87-97.

[20] Huang Y X, Wang B T, Yao Y X, Ding S P, Zhang J C, Zhu R X Parameter optimization of fluted-roller meter using discrete element method. Int J Agric \& Biol Eng, 2018; 11(6): 65-72.

[21] Liu L J, Yang H, Ma S C. Experimental study on performance of pneumatic seeding system. Int J Agric \& Biol Eng, 2016; 9(6): 84-90.

[22] Arzu Y, Adnan D. Optimisation of the seed spacing uniformity performance of a vacuum-type precision seeder using response surface methodology. Biosystems Engineering, 2007; 97: 347-356.

[23] Aykas E, Yildiz E P. The accuracy in seed spacing of a seeder with variable ratio. In: Ertekin C, editor. XIX world congress of CIGR (International Commsion of Agricultural and Biosystem Engineering), Antalya, Turkey, 2018; pp.326-337.

[24] Iqbal M, Muneer A M, Hussain K A, Umair M. Evaluation of the energy efficient zone disk drill for sowing of wheat after harvesting paddy crop. Internation Journal of Agriculture and Biology, 2012; 14: 633-636.

[25] Muneer A M, Iqbal M, Miran S. Evaluation of three seed furrow openers mounted on a zone disk tiller drill for residue management, soil physical properties and crop parameters. Pakistan Journal of Agriculture Sciences, 2012; 49: 349-355.

[26] Karayel D, Özmerzi A. Effect of tillage methods on sowing uniformity of maize. Canadian Biosystem Engineering, 2002; 44: 23-26.

[27] Altikat S. Effects of strip width and tractor forward speed on sowing uniformity of maize and sunflower. Bulgarian Journal of Agricultural Science, 2013; 18: 375-381.

[28] Shi S, Zhang D X, Yang L, Cui T, Zhang R, Yin X W. Design and experiment of pneumatic maize precision seed meter with combined holes. Transactions of the CSAE, 2014; 30(5): 10-18. (in Chinese) 